\title{
RADIO-IODINE THERAPY IN HYPERTHYROIDISM- A STUDY OF 50 CASES
}

\author{
ATIN KUMAR SHAHA ${ }^{1}$, MD. JAHANGIR ALAM ${ }^{2}$, MA RASHID ${ }^{3}$, MIRZA AZIZUL HOQUE ${ }^{4}$, MOSHIUR \\ RAHMAN KHASRU ${ }^{5}$, HAM NAZMUL AHASAN ${ }^{6}$
}

\begin{abstract}
:
The use of radioiodine- ${ }^{131}$ for the treatment of hyperthyroidism is a very simple and cheap form of therapy and highly effective and is now the predominant definitive therapy both as primary treatment and following relapse after anti thyroid drugs. This study was carried out in Khulna medical college from January 2002 to January 2003 to assess the degree of effectiveness of radioiodine therapy in case of hyperthyroidism. This was a prospective study of 50 patients with hyperthyroidism (28 female, 22 male, mean age 39.87 years) treated with radioiodine- ${ }^{131}$ and followed up for a period of one year. The dose of radioiodine ${ }^{-131}$ ranged from 7-10 mci. Out of 50 patients $38(76 \%)$ were found to have diffuse toxic goitre, $5(10 \%)$ have solitary toxic nodule $1(2 \%)$ have multi nodular toxic goitre, 4(8\%) have impalpable gland with thyrotoxicosis and 2(4\%) with relapsing thyrotoxicosis received oral radioiodine therapy. Serum $T_{3}$ was elevated in 43(86\%) and was normal in 7(14\%) cases. Serum $T_{4}$ was normal in $4(8 \%)$ cases that were $T_{3}$ thyrotoxicosis and rose in 46(92\%) cases. Serum TSH was reduced in all cases. Thyroid scan shows warm / diffuse uptake in 44 (88\%) and hot nodule in 6(12\%) cases.

Post therapy clinical and biochemical evaluation of thyroid function was done at 3 months, 6 months, 9 months and 12 months interval. The patient was classified as cured if the biochemical status was either euthyroid or hypothyroid at one year without further treatment by antithyroid drugs or radioiodine. The incidence of euthyroid, hypothyroidism and hyperthyroidism within one year was $60.00 \%, 35.60 \%$ and $4.40 \%$ and the cure rate was $95.6 \%$. From this study we found that radioiodine- ${ }^{131}$ therapy is a simple, safe and effective means to normalize thyroid function status in patients with hyperthyroidism.
\end{abstract}

\section{Introduction:}

Disorders of thyroid gland result primarily from autoimmune processes that either stimulates the overproduction of thyroid hormone (Hyperthyroidism) or cause glandular destruction and under production of thyroid hormone (hypothyroidism). ${ }^{1}$ Both the conditions are not uncommon and hyperthyroidism is an important disorder in our country. ${ }^{2}$ The conventional treatment of hyperthyroidism includes antithyroid drugs, surgery and radioiodine-131 therapy. Each form of treatment has specific indications, advantages \& disadvantages. ${ }^{3}$ Radioiodine has the advantage if being a very simple and cheap form of therapy and highly effective and is now the predominant definitive therapy both as primary treatment and following relapse after antithyriod drugs. ${ }^{1,}$ 4, 5 In Bangladesh a few studies have been done on this topic which show radioiodine therapy is an effective means of treatment, although those are not still sufficient to cover the topic in our country. We have done this study in Khulna medical college hospital from January 2002 to January 2003. It was undertaken to find out the effectiveness of radio-iodine therapy in controlling hyperthyroidism \& to observe the short term outcome of radio-iodine treatment.

\section{Materials and Methods:}

Fifty cases of hyperthyroidism diagnosed by usual clinical and biochemical criteria including raised $\mathrm{T}_{3}$, T4 \& suppressed TSH from Khulna Medical College Hospital (KMCH) and Centre for Nuclear Medicine \& Ultrasound, Khulna, were selected for the study. Radio

1. MD Student (Nephrology-Thesis), Bangabandhu Shaiekh Mujib Medical University.

2. MD Student, Internal Medicine (Thesis), Dhaka Medical College Hospital.

3. Assistant Professor, Department of Anatomy, Bangladesh Medical College.

4. Assistant Professor (Endocrinology), Dhaka Medical College, Dhaka.

5. Medical Officer, SPRC Hospital, New Eskaton Road, Dhaka

6. Professor of Medicine, Dhaka Medical College, Dhaka. 
nuclide scan was performed in all cases, post therapy follow up was done at 3 months, 6 months, 9 months, 1 year. Clinical \& biochemical evaluation was assessed in each follow up visit. Serum $\mathrm{T}_{3}$ and $\mathrm{T}_{4}$ was measured by radioimmunoassay technique and TSH by immuno radiometric assay technique.

Elderly patients and all those with cardiac disease and severe hyperthyroidism were pretreated with a short course of antithyroid drugs in full dosages until they were clinically and biochemically euthyroid. Antithyroid drugs were stopped 3 days before radioiodine administration. No patient had posttreatment antithyroid drugs during follow-up period. Before administering radioiodine, the nature of treatment, the importance of precautionary measures and follow-up necessity was explained to the patients.

\section{Results:}

Out of fifty patients the maximum age was 75 years and the minimum age 17 years. The mean age was 39.87 years. Of these patients (Table I) females were more sufferer 28 (56\%) than the male 22 (44\%). Male (22) and female (28) ration was 1:1.2 The highest number of patient belongs to 30-34 and 40-44 age groups and least number belongs to $20-24$ age group (Fig 1).

Table-I

Sex distribution of studied patient $(n=50)$

\begin{tabular}{lcc}
\hline Total no. of patient & 50 & $\%$ \\
\hline Mean age -39.8 years & & \\
No. of male patients & 22 & 44 \\
No. of female patients & 28 & 56 \\
\hline
\end{tabular}

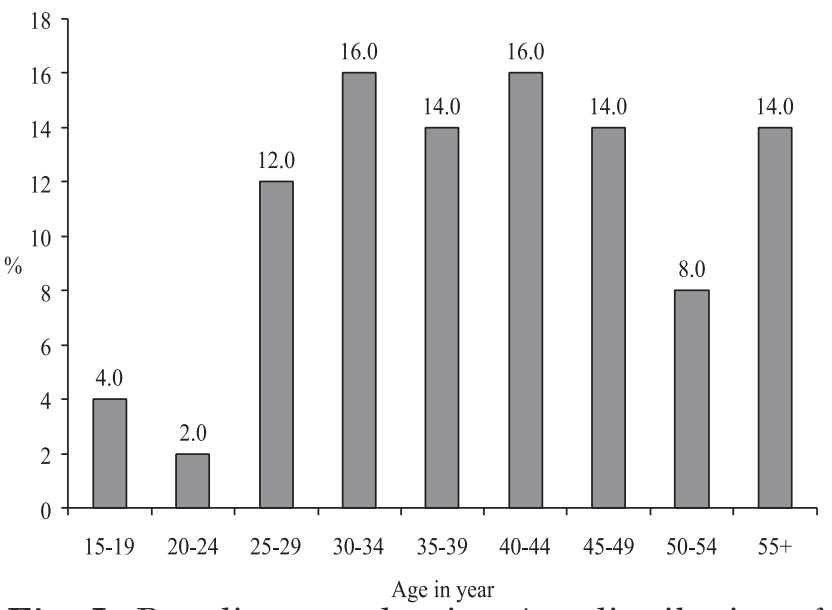

Fig. I: Bar diagram showing Age distribution of studied patients $(n=50)$.
Out of 50 patients 38 (76\%) were found to have defuse toxic goitre, $5(10 \%)$ solitary toxic nodule, $1(2 \%)$ multinodular toxic goitre, 4(8\%) impalpable gland with thyrotoxicosis and $2(4 \%)$ with relapsing thyrotoxicosis received oral radioiodine therapy (Table II).

Table-II

Presentation of patient with hyperthyroidism $(n=50)$

\begin{tabular}{lcc}
\hline Pattern & $\begin{array}{c}\text { No. of } \\
\text { Patient }\end{array}$ & $\begin{array}{c}\text { Percentage } \\
(\%)\end{array}$ \\
\hline Diffuse Toxic Goitre & 38 & 76 \\
Solitary Toxic Nodule & 5 & 10 \\
Multinodular Toxic Goitre & 1 & 2 \\
Impalpable gland with & 4 & 8 \\
Thyrotoxicosis & & \\
Relapsing Thyrotoxicosis & 2 & 4 \\
\hline
\end{tabular}

Routine blood count with $\mathrm{Hb} \%$, serum $\mathrm{T}_{3}, \mathrm{~T}_{4}, \mathrm{TSH}$, radioactive iodine uptake test, thyroid scan, ECG, xray chest P/A view was done in all cases. Serum $\mathrm{T}_{3}$ was elevated in $43(86 \%)$ and was normal in $7(14 \%)$ cases (Table-III). Serum $\mathrm{T}_{4}$ was normal in $4(8 \%)$ cases that were $\mathrm{T}_{3}$ thyrotoxicosis and raised in 46(92\%) cases, Serum TSH was reduced in all 50 cases. ECG shows sinus tachycardia in 22 (44\%), LVH \& AF in 1 (2\%) \& normal in 27 (54\%) cases. Thyroid scan showed warm/diffuse uptake in 44 (88\%), hot nodule in 6(12\%) cases, X-ray chest P/A view was done in $49(98 \%)$ cases $\&$ in one case showed cardiomegaly. Ultra sonogram of thyroid gland revealed 5 solitary nodules with 1 multinodular goitre \& 40 diffuse goitre $\&$ in 4 cases there is no detectable goitre.

Table - III

Laboratory evaluation of thyroid function in hyperthyroid patients.

\begin{tabular}{llcc}
\hline & Value & No. of Patient & $\%$ \\
\hline $\mathrm{T}_{3}$ & 1-2.6 nmol/L & 7 & 14 \\
& Elevated & 43 & 86 \\
$\mathrm{~T}_{4}$ & 60-160 nmol/L (normal) & 4 & 8 \\
& Elevated & 46 & 92 \\
$\mathrm{TSH}$ & $0.3-3.5 \mathrm{Mn} / \mathrm{L}$ (normal) & 0 & 0 \\
& Reduced & 50 & 100 \\
\hline
\end{tabular}


On follow up 5 patients lost after first follow up at 3 months. Of the 45 patients $27(60 \%)$ were euthyroid, $16(35.6 \%)$ became hypothyroid and replacement therapy by thyroxin were started, 2(4.4\%) remaining hyperthyroid and they were treated by second dose of radioiodine therapy. Of 16 patients who became hypothyroid after getting radioiodine therapy, 5 patients become hypothyroid within three months, 3 patients within 6 months, 6 patients within 9 months and 2 patients within 1 year(Table IV). No adverse effect of radioiodine drink was observed. After follow up 27(60\%) patients become euthyroid, 16(35.6\%) patients become hypothyroid and $2(4.4 \%)$ patients remained as hyperthyroid (Table V).

\section{Table-IV}

Shows the follow-up finding on 3, 6, 9 months and 1 years after radioiodine therapy.

\begin{tabular}{lcccc}
\hline Thyroid & \multicolumn{4}{c}{ No. of Patient } \\
& $\begin{array}{c}\text { At. 3 } \\
\text { months }\end{array}$ & $\begin{array}{c}\text { At 6 } \\
\text { months }\end{array}$ & $\begin{array}{c}\text { At 9 } \\
\text { months }\end{array}$ & $\begin{array}{c}\text { At 1 } \\
\text { Years }\end{array}$ \\
\hline Hyperthyroid & 43 & 19 & 9 & 2 \\
Euthyroid & 02 & 18 & 22 & 27 \\
Hypothyroid & 05 & 08 & 14 & 16 \\
\hline Total & 50 & 45 & 45 & 45 \\
\hline
\end{tabular}

Table-V

Follow up result after radioiodine therapy

\begin{tabular}{lcc}
\hline & No. of patients & Percentage \\
\hline Euthyroid & 27 & 60 \\
Hypothyroid & 16 & 35.6 \\
Persistent hyperthyroid & 2 & 4.4 \\
\hline Total & 45 & 100 \\
\hline
\end{tabular}

\section{Discussion:}

Hyperthyroidism is the clinical syndrome, which results from exposure of the body tissue to excess circulating levels of free thyroid hormone. The diagnosis of hyperthyroidism is done by raised T3 \& $\mathrm{T} 4$ in majority, but $\mathrm{T} 4$ is in upper part of normal range \& T3 raised (T3 thyrotoxicosis) may present in $5 \%$ of patients. In primary hyperthyroidism serum TSH is undetectable at less than $0.1 \mathrm{ml} / \mathrm{L}$.Radioiodine acts either by destroying functioning thyroid cells or by inhibiting their ability to replicate and eventually thyroid functional status will turn from hyper function state to euthyroid or hypothyroid state as well as thyroid size reduction will occur. ${ }^{6,7,8}$ Radioiodine treatment of thyrotoxicosis is considered one of, if not the most, successful therapy in Nuclear Medicine.

In this series our purpose was to evaluate the effectiveness of radioiodine controlling hyperthyroidism and the short term outcome of radioiodine treatment. All patients were enrolled for radioiodine therapy. Follow up was done at 3 monthly for the $1^{\text {st }}$ year. Clinical \& biochemical evaluation of thyroid functions was assessed in each follow-up visit. Of these 50 cases, $38(76 \%)$ patients of diffuse toxic goitre, $5(10 \%)$ patients of impalpable glands with thyrotoxicosis and 2(4\%) relapsing thyroxicosis received radioiodine therapy. (34\%) patients with higher hormone level or other medical complication like cardiovascular problems were pretreated with antithyroid drugs. The drug was discontinued 3 days before receiving radioiodine therapy. Rest of the patients received either no treatment or beta-blocker drug prior to radioiodine therapy. In this current series about $60 \%$ become euthyroid which is a better result in comparison to other study done by Sankar et al in India. ${ }^{9}$ Hypothyroidism is an inevitable consequence of the treatment of hyperthyroidism with radioactive iodine and almost certainly would occur in all patients if they lived long enough. ${ }^{10,11}$ In our study 16(35.6\%) patients became hypothyroid after therapy. Hypothyroidism that occurs in the first year following radioactive iodine therapy is related to dose, while the subsequent occurrence is due to a combination of radiation-mediated injury and underlying autoimmunity. ${ }^{12}$ Hence current practice guidelines, recommend large single dose because attempting to achieve permanent euthyroidism with radioactive iodine is nearly impossible. ${ }^{13,14}$

Though due to small sample size with short follow up period which preclude any firm conclusion of long term effects of radioiodine therapy. In our observation hyperthyroidism was controlled with single dose of 1 131 in most of the cases as an effective means of treatment with change of essentially unavoidable hypothyroidism. Further long term research is needed in this regard.

\section{References:}

1. Fauci AS,Kasper DL,Hauser SL.In:Harrisons Principles of Internal Medicine, $17^{\text {th }}$ ed.Newyork:McGraw-Hills company,2008; vol 2:202-98. 
2. Paul AK, Miah MSR, Ansari SM. Radioiodine in hyperthyroidism using fixed dose regime. Bangladesh Med J (Khulna) 1998; 31(2): 34-7.

3. Solomon B, Glinoer D, Lagusee R, Wartofsky L. Current trends in the management of Graves' disease. J Clin Endocrinol Metab 1990; 70:1518-24.

4. T.W. Sadler.In: Langman's Medical Embryology, 9th Edi.Edinburgh: Lange, 2004:384.

5. Brook CGD, Marshal NJ.Essential Endrocrinology, 3rd Edi.Newyork: Lange, 1996:76-9.

6. Hennemann G, Grenning EP, Sankaranarayann K. Place of radioactive iodine in treatment of thyrotoxicosis. Lancet 1984; 11: 1369-72

7. S Yasmeen, K Ahmed, F Kabir. A report on follow up of treatment of hyperthyroidism with radioiodine. Bangladesh Med Res Counc Bull 1988; 14: 42-47

8. Ratcliffe GE, Fogelman I, Maisey MN. The evaluation of radioiodine therapy for thyroid patients using a fixed dose regime. BJR 1986; 59: 1105-1107.

9. Sankar R,Sekhri T,Sripathy G,Walia RP,Jain SK.Radioactive Iodine therapy in Graves' hyperthyroidism: A Prospective study from a Tertiary referral center in North India.JAPI 2005; 53: $603-6$.
10. Alevizaki CC, Alevizaki-Harhalaki, Ikkos DG. Radioiodine -131 treatment of thyrotoxicosis: dose required for and some factors affecting the early induction of hypothyroidism. Eur J Nucl Med 1985; 10: $450-54$.

11. Cevallos JL, Hagen GA, Maloof F, Chapman EM. Low-dosage 131I therapy of thyrotoxicosis(diffuse goiters). A five-year follow-up study. N Eng J Med 1974; 290: 141-44.

12. Becker DV, McConahey WM, Dobins BM, et al. The results of thyrotoxicosis therapy follow up study.In:Fellinger K,Hofer R (eds).Further advances in thyroid research.Vienna:G Gitsel und Cie 1971; 1: 603-609.

13. Sawin CT, Becker DV. Radioiodine and treatment of hyperthyroidism: The early history. Thyroid 1997; 7: 163-176.

14. Guidelines for the use of radioiodine in the management of hyperthyroidism : A summary. Prepared by the radioiodine audit subcommittee of the Royal College of Physicians Committee on diabetes and endocrinology and the research unit of the Royal College of Physicians. J R Coll Physicians London 1995; 29: 464-69. 